\title{
UPPSALA NATURAL RADIOCARBON MEASUREMENTS IV
}

\author{
INGRID U. OLSSON and SERAP KILICCI* \\ Fysiska Institutionen, Uppsala Universitet, Uppsala, Sweden
}

The following list covers most of the samples measured at the Uppsala $\mathrm{C}^{14}$ laboratory since the last list (Uppsala III) except for all the samples utilized for determining the increase of the $\mathrm{C}^{14} / \mathrm{C}^{12}$ ratio due to explosion of nuclear devices and the few samples measured with a new proportional counter.

The technique used is the same as previously described by Olsson (1958) and the pretreatment is that which has been used earlier (wood, charcoal, peat, gyttja and other organic sediments are boiled with $\mathrm{HCl}, 1$ to $2 \%$, washed with distilled water, kept in $\mathrm{NaOH}, 1$ to $2 \%$, at $+80^{\circ} \mathrm{C}$ over night, washed with distilled water and finally acidified to $\mathrm{pH}$ about 3 before being dried) except for Foraminifera tests, see below.

The reference sample is $95 \%$ of the activity of the NBS oxalic-acid standard. Any corrections for apparent water ages are thus not included here, but will be discussed in later papers dealing with the marine samples. Corrections for deviations from the normal $\mathrm{C}^{13} / \mathrm{C}^{12}$ ratio $(-25.0 \%$ in the PDB scale) are applied for the unknown samples. Our oxalic acid was measured by Craig (1961) and has a $\mathrm{C}^{13} / \mathrm{C}^{12}$ ratio of $-18.97 \%$ and corresponds to the accepted standardized value, $-19 \%$, which should be used for age determinations (Editorial Statement in Radiocarbon, v. 3). Two new combustions of oxalic acid have not shown any significant difference in their $\mathrm{C}^{13}$ content relative to the oxalic acid 1 sample measured by Craig.

The value $5570 \mathrm{yr}$ has been used for the half-life of $\mathrm{C}^{14}$. Results are expressed in years before 1950 (в.P.). Errors include the standard deviations ( $\sigma$ ) of the counted particles as well as the error in the $\delta \mathrm{C}^{13}$ values. When the activity is very low, so that $2 \sigma$ corresponds to a possibility of infinite age, $2 \sigma$ has been used instead of $\sigma$.

Several samples had to be diluted with $\mathrm{CO}_{2}$ from an old source to bring them to the normal working pressure of $3 \mathrm{~atm}$.

\section{ACKNOWLEDGMENTS}

Descriptions of the samples are based on information provided by those responsible for collecting and submitting them. Before the final manuscript was ready, most contributors were kind enough to read the draft and suggest improvements. Sincere thanks are due to them. Special thanks are also due Dr. R. Ryhage and his co-workers for making the $\mathrm{C}^{13} / \mathrm{C}^{12}$ determinations; Prof. K. Siegbahn, who has made it possible to do this work at the institute; and Statens Naturvetenskapliga Forskningsråd, which has given the laboratory financial support. The authors are indebted to Fil. kand. P. Kållberg for his assistance in programming the IBM 1620 for calculating ages and Fil. mag. Anders Ingemarsson for taking part in the dating during the autumn 1962, and to Miss

* On leave from the Middle East Technical University, Ankara, Turkey. 
Birgitta Wallin and Miss Maud Söderman who began taking part in the work in February and April 1963 respectively.

One of us (S.K.) would like to acknowledge a fellowship from the Swedish Agency for International Assistance through the International Seminar for Research and Education in Physics.

\section{SAMPLE DESCRIPTIONS}

\section{GEOLOGIC SAMPLES}

\section{A. Mediterranean Area}

\section{Western Mediterranean Sea series}

Foraminifera tests from deep-sea cores. Coll. 1948 by Swedish Albatross Expedition (Pettersson) ; subm. by K. Gösta Eriksson, Kvartärgeologiska Inst., Uppsala Univ., Uppsala, Sweden. All present and previous samples of sediment core No. 210 are described by Eriksson (1964) and samples from the other two sediment cores Nos. 209 and 211 will be described later by Eriksson. The Foraminifera analyses were made by Todd (1958). Comment: samples did not contain enough coarse fraction $(>74 \mu)$ for separate measurements as suggested by Rubin and Suess (1955) and Ericson and others (1956). An investigation has been initiated in order to determine the most suitable choice of fractions for $\mathrm{C}^{14}$ dating; so far, 2 samples have been investigated after the material was separated into three fractions $(>44 \mu, 4-44 \mu$, and $<4 \mu)$. Results show that finer fractions may give erroneous results. Another important con-

TABLE 1

Contamination of "infinitely" old material with recent material due to different dispersing media

\begin{tabular}{|c|c|c|c|c|}
\hline $\begin{array}{l}\text { Laboratory } \\
\text { No. }\end{array}$ & Dispersing medium ${ }^{a}$ & $\begin{array}{l}\text { Apparent age } \\
\text { years }\end{array}$ & $\delta \mathrm{C}^{13} \%$ & $\begin{array}{l}\text { Net counting rate } \\
\text { (contamination) } \\
\text { counts } / \text { min }\end{array}$ \\
\hline $\mathrm{U}-287$ & Dist. $\mathrm{H}_{2} \mathrm{O}$ & $\begin{array}{r}33,800+2400 \\
-1900\end{array}$ & -7.5 & $0.14 \pm 0.03$ \\
\hline U-288 & $\mathrm{NH}_{4} \mathrm{OH} 0.1 \%$ & $\begin{array}{r}32,000+1600 \\
-1400\end{array}$ & -8.2 & $0.18 \pm 0.03$ \\
\hline U-289 & Dist. $\mathrm{H}_{2} \mathrm{O}^{\mathrm{b}}$ & $\begin{array}{r}37,400+3600 \\
-2500\end{array}$ & -7.5 & $0.09 \pm 0.03$ \\
\hline U-290 & Boiled dist. $\mathrm{H}_{2} \mathrm{O}$ & $>40,000$ & -7.7 & $0.02 \pm 0.03$ \\
\hline U-291 & $\mathrm{NH}_{4} \mathrm{OH} 0.1 \%$ & $\begin{array}{r}36,500+3100 \\
-2300\end{array}$ & -7.3 & $0.10 \pm 0.03$ \\
\hline U-292 & $\begin{array}{l}\text { Dil. } \mathrm{HCl} \\
(\mathrm{pH}=4.0)\end{array}$ & $>40,000$ & -7.5 & $0.05 \pm 0.03$ \\
\hline \multicolumn{5}{|c|}{$\begin{array}{l}1 \mathrm{~L} \text { medium }+0.5 \mathrm{~L} \text { wash liquid of same composition. } \\
\text { Following filtration this sample was treated with } 5 \mathrm{ml} \text { of dil. } \mathrm{HCl}(\mathrm{pH}=4.0) \text { and } \\
\text { dried in the oven at } 105^{\circ} \mathrm{C} \text {. } \\
\text { The apparent ages are the results, within the limits of error, corresponding to the net } \\
\text { counting rates, due to contamination. The errors given are the statistical errors. The } \\
\text { accepted value of } 5570 \text { yr is used for the half-life of } \mathrm{C}^{14} \text {. The } \delta \mathrm{C}^{13} \text { values give the } \mathrm{C}^{13} \\
\text { enrichment relative to the Chicago PDB standard }(\mathrm{Craig} \text {, 1961). } 95 \% \text { of the net count- } \\
\text { ing rate of the NBS oxalic acid gives } 9.31 \text { counts } / \text { min in the proportional counter. }\end{array}$} \\
\hline
\end{tabular}


sideration is preparation of core material. It has been shown that it is important to use water that is free from $\mathrm{CO}_{2}$ (Table 1). The investigations are treated in detail by Eriksson and Olsson (1963) and Olsson and Eriksson (1964).

$$
\begin{array}{lll}
\text { U-293. Core } 20903,145 \text { to } 155 \mathrm{~cm},>44 \mu & 14,200 \begin{array}{l}
+480 \\
\mathbf{- 4 6 0}
\end{array} \\
& 12,250 \text { в.C. }
\end{array}
$$

Core $20903\left(38^{\circ} 31^{\prime} \mathrm{N}\right.$ Lat, $03^{\circ} 50^{\prime}$ E Long), depth 145 to $155 \mathrm{~cm}$, depth in the sea $2596 \mathrm{~m}$. Level corresponds to marked increase of Globigerina inflata and second increase of Globigerinoides rubra. Comment: fraction $>44 \mu$ was used; dist. $\mathrm{H}_{2} \mathrm{O}$ was dispersing medium. Diluted. $\delta \mathrm{C}^{13}=-3.2 \%$.

$$
\begin{aligned}
& \text { U-294. Core 20903, } 145 \text { to } 155 \mathrm{~cm}, 4-44 \mu \quad 26,600 \quad \begin{array}{l}
+830 \\
-760
\end{array} \\
& 24,650 \text { в.c. }
\end{aligned}
$$

The same sample as U-293 but fraction $4-44 \mu$ was used. $\delta \mathrm{C}^{13}=-1.2 \%$.

$$
\begin{array}{ll}
\text { U-295. Core } 20903,145 \text { to } 155 \mathrm{~cm},<4 \mu & 17,300 \quad \begin{array}{l}
+300 \\
\mathbf{2 9 0}
\end{array} \\
15,350 \text { в.c. }
\end{array}
$$

The same sample as U-293, but fraction $<4 \mu$ was used. $\delta \mathrm{C}^{13}=0.0 \%$.

$$
\begin{array}{lll}
\text { U-296. Core } 21107,428 \text { to } 440 \mathrm{~cm},>44 \mu \quad 16,700 & +1200 \\
-1100 & 14,750 \text { в.c. }
\end{array}
$$

Core 21107 ( $35^{\circ} 55^{\prime} \mathrm{N}$ Lat, $02^{\circ} 20^{\prime} \mathrm{W}$ Long), depth 428 to $440 \mathrm{~cm}$, depth in sea $1325 \mathrm{~m}$. Dominance of Globigerina pachyderma and Globigerina eggeri and absence of warm-tolerant species. Comment: fraction $>44 \mu$ was used; boiled dist. $\mathrm{H}_{2} \mathrm{O}$ was dispersing medium. Diluted. $\delta \mathrm{C}^{13}=+0.1 \%$.

$$
\begin{array}{ll}
\text { U-297. Core } 21107,428 \text { to } 440 \mathrm{~cm}, 4-44 \mu & 22,300 \quad \begin{array}{l}
+750 \\
-690
\end{array} \\
20,350 \text { в.c. }
\end{array}
$$

The same as U-296 but fraction $4-44 \mu$ was used. Diluted. $\delta \mathrm{C}^{13}=-2.3 \%$.

$$
\begin{array}{ll}
\text { U-298. Core } 21107,428 \text { to } 440 \mathrm{~cm},<4 \mu & \mathbf{2 1 , 2 0 0} \begin{array}{c}
+430 \\
-410
\end{array} \\
19,250 \text { в.c. }
\end{array}
$$

The same as U-296 but fraction $<4 \mu$ was used. $\delta \mathrm{C}^{13}=0.0 \%$.

$$
\begin{array}{ll}
\text { U-251. Core } 21007,390 \text { to } 398 \mathrm{~cm},>44 \mu & 13,180 \pm 300 \\
\text { 11,230 в.c. }
\end{array}
$$

Core $21007\left(37^{\circ} 26^{\prime} \mathrm{N}\right.$ Lat $01^{\circ} 05^{\prime} \mathrm{E}$ Long), in sea $2782 \mathrm{~m}$. Level is in transition zone between cool-tolerant and warmtolerant Foraminifera species. Comment: fraction $>44 \mu$ was used; tap water was dispersing medium. Diluted. $\delta \mathrm{C}^{13}=-9.7 \%$.

$$
\text { U-252. Core 21009, } 527 \text { to } 537 \mathrm{~cm},>44 \mu \quad 17,250 \pm 370
$$

Core 21009 ( $37^{\circ} 26^{\prime} \mathrm{N}$ Lat, $01^{\circ} 05^{\prime} \mathrm{E}$ Long), depth 527 to $537 \mathrm{~cm}$, depth in sea $2782 \mathrm{~m}$. Dominance of cool-tolerant Foraminifera species. Comment: fraction $>44 \mu$ was used; dist. $\mathrm{H}_{2} \mathrm{O}$ was dispersing medium. Diluted. $\delta \mathrm{C}^{13}=$ $-2.8 \%$. 


\section{U-253. Core 21011,663 to $675 \mathrm{~cm},>44 \mu \quad 22,000 \quad \begin{array}{r}+1000 \\ -800\end{array}$ \\ 20,050 в.с.}

Core $21011\left(37^{\circ} 26^{\prime} \mathrm{N}\right.$ Lat, $01^{\circ} 05^{\prime} \mathrm{E}$ Long), depth 663 to $675 \mathrm{~cm}$, depth in sea $2782 \mathrm{~m}$. Dominance of cool-tolerant Foraminifera species. Highest abundance of Globigerina pachyderma in core No. 210. Comment: fraction $>44 \mu$ was used; dist. $\mathrm{H}_{2} \mathrm{O}$ was dispersing medium. Diluted. $\delta \mathrm{C}^{13}=-7.1 \%$.

\section{U-254. Core 21014, 850 to $865 \mathrm{~cm},>44 \mu \quad 30,100+1200$ 28,150 в.c.}

Core 21014 (37 $26^{\prime} \mathrm{N}$ Lat, $01^{\circ} 05^{\prime}$ E Long), depth 850 to $865 \mathrm{~cm}$, depth in sea $2782 \mathrm{~m}$. Level corresponds to increase of Globigerina pachyderma. Comment: fraction $>44 \mu$ was used; dist. $\mathrm{H}_{2} \mathrm{O}$ was dispersing medium. Diluted. $\delta \mathrm{C}^{13}=-4.3 \%$.

\section{U-255. Core 21001, 23 to $29 \mathrm{~cm},>44 \mu \quad 5880 \pm 100$}

Core $21001\left(37^{\circ} 26^{\prime} \mathrm{N}\right.$ Lat, $01^{\circ} 05^{\prime} \mathrm{E}$ Long), depth 23 to $29 \mathrm{~cm}$, depth in sea $2782 \mathrm{~m}$. Comment: fraction $>44 \mu$ was used; dist. $\mathrm{H}_{2} \mathrm{O}$ was dispersing medium. Diluted. $\delta \mathrm{C}^{13}=-2.3 \%$.

$$
\begin{array}{lc}
\text { U-300. Core } 21105,262 \text { to } 272 \mathrm{~cm},>44 \mu & 10,290 \pm 290 \\
\mathbf{8 3 4 0} \text { в.c. }
\end{array}
$$

Core 21105 ( $35^{\circ} 55^{\prime} \mathrm{N}$ Lat, $02^{\circ} 20^{\prime} \mathrm{W}$ Long), depth 262 to $272 \mathrm{~cm}$, depth in sea $1325 \mathrm{~m}$. Dominance, although a decrease, of Globigerina pachyderma and Globigerina eggeri and increase of Globigerinoides rubra and Globigerina inflata. Comment: fraction $>44 \mu$ was used; dist. $\mathrm{H}_{2} \mathrm{O}$ was dispersing medium. Diluted. $\delta \mathrm{C}^{13}=-2.0 \%$.

\section{Correction to sample U-142 in Uppsala II :}

U-142. Core 21104, 223 to $227.5 \mathrm{~cm}$

$10,800 \pm 400$

Core 21104 $\left(35^{\circ} 55^{\prime} \mathrm{N}\right.$ Lat, $02^{\circ} 20^{\prime} \mathrm{W}$ Long $)$, depth 223 to $227.5 \mathrm{~cm}$, depth in the sea $1325 \mathrm{~m}$. Level corresponds to increase of Globigerinoides rubra and decrease of Globorotalia scitula. Comment: fraction $>4 \mu$ was used. $\delta \mathrm{C}^{13}=+20.0 \%$. Comment: U-142 given as previously published, with typographic errors corrected, and with reference to same standards as in Uppsala II. With oxalic acid and PDB as standards age is $10,930 \pm 400$ B.P. and $\delta \mathrm{C}^{13}$ is $-4 \%$.

\section{B. Africa}

\section{U-266. Abidjan CI 60/1 e}

$$
950 \pm 70
$$

Salt water lagoon mollusc shells, accumulated by wave action, from Adiopodioume, Abidjan ( $5^{\circ} 10^{\prime} \mathrm{N}$ Lat, $3^{\circ} 50^{\prime} \mathrm{W}$ Long), Ivory Coast. Sample from a $50 \mathrm{~cm}$ thick layer of shells, $48 \mathrm{~m}$ alt. Coll. 1960 and subm. by J. Tricart. Centre de Géog. Appliquée et Inst. de Géog., Univ. de Strasbourg, Strasbourg, France. Comment: inner $17 \%$ was used. $\delta \mathrm{C}^{13}$ not measured but assumed to be $-5.2 \%$. 


\section{U-265. Abidjan CI 60/1 b}

$990 \pm 70$

Shell layer surrounding the part used for sample U-266. Comment: layer corresponds to $34 \%$ of the shells. $\delta \mathrm{C}^{13}=-5.8 \%$.

\section{U-264. Abidjan CI 60/1 a}

$970 \pm 110$

Shell layer surrounding the part used for sample U-265. Comment: layer corresponds to $42 \%$ of the shells. $7 \%$ was removed by washing. $\delta \mathrm{C}^{13}=$ $-4.6 \%$.

\section{Sogho-nor series}

\section{Asia}

Shells coll. by N. Hörner at the lake Sogho-nor $\left(42^{\circ} \mathrm{N}\right.$ Lat, $101^{\circ} \mathrm{E}$ Long $)$ and at Camp H82 $\left(40^{\circ} 34^{\prime} \mathrm{N}\right.$ Lat, $\left.90^{\circ} 10^{\prime} \mathrm{E} \mathrm{Long}\right)$ near the lake Lop-nor, Turkestan. Shells are probably freshwater but of unknown species. Finite ages may be too great, owing to recycling of carbonates, but age of two old samples is probably minimum if there has been atmospheric contamination. Measure-

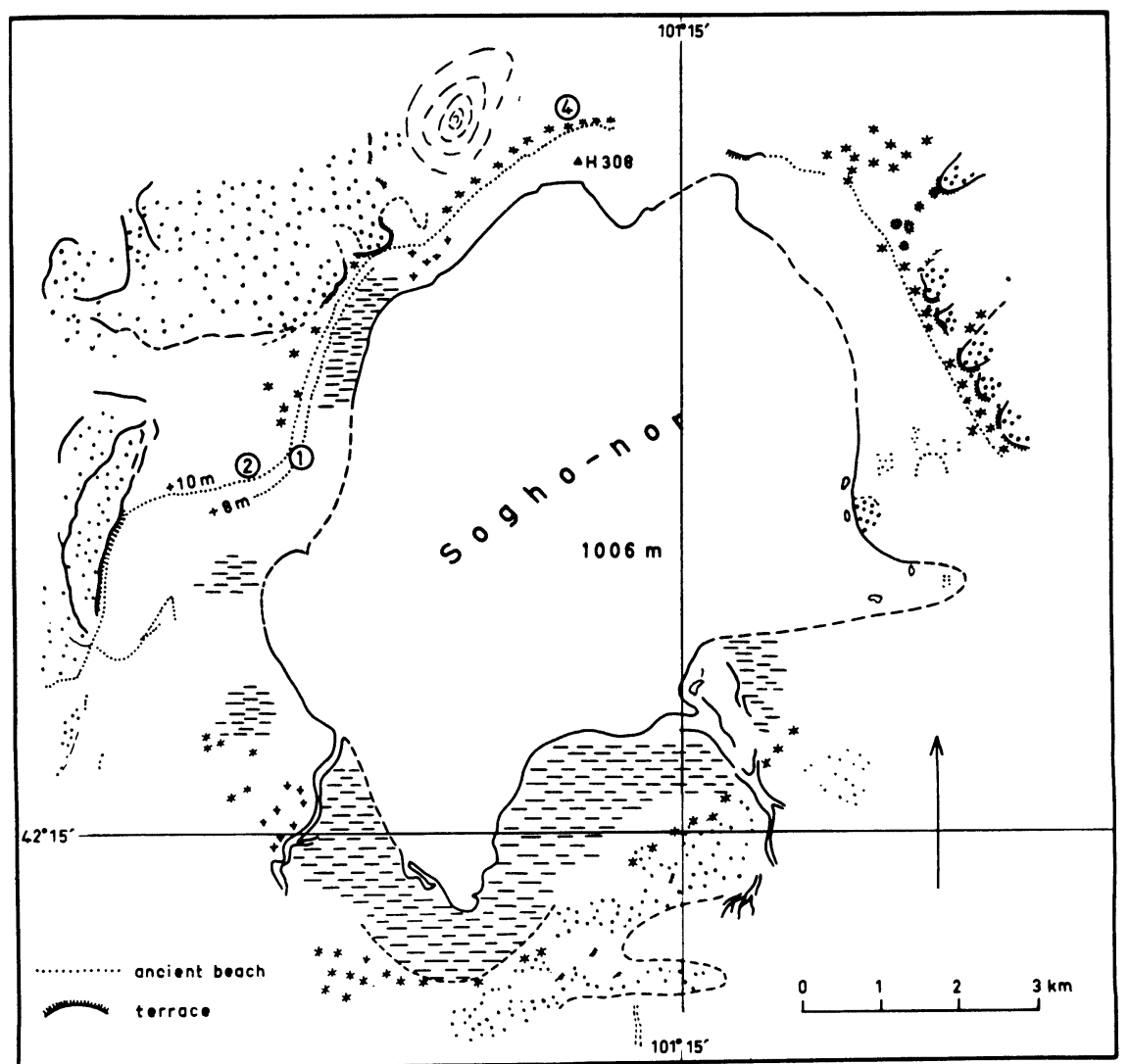

Fig. 1. Map showing the lake Sogho-nor and its beaches. 
ments were undertaken in an effort to contribute some new information to an exceptionally interesting problem, described by Hörner and Chen (1935) and discussed anew by Norin (in preparation). The map (Fig. 1) shows Sogho-nor and its beaches.

\section{U-281. Sogho-nor 040233 AB \\ 31,750 в.с.}

Shells on surface of uppermost terrace, $151 / 2 \mathrm{~m}$ above level of lake on collection day, Locality 4 on the map $\mathrm{N}$ of Camp H308. Coll. Febr. 4, 1933 by Hörner; subm. by Erik Norin, Mineralogisk-geologiska Inst., Uppsala Univ., Uppsala, Sweden. Comment: inner $86 \%$ was used. $\delta \mathrm{C}^{13}=-5.1 \%$.

\section{U-280. Sogho-nor 270530 shell \\ 32,250 в.с.}

Shells in ancient gravelly beach $8 \mathrm{~m}$ above level of lake on collection day, and in silt accumulated behind the ridge, Locality 1 on the map. Shells probably derived from adjoining terrace sediments. Coll. May 27, 1930 by Hörner; subm. by Norin. Comment: inner $57 \%$ was used. $\delta \mathrm{C}^{13}=-4.8 \%$.

\section{U-286. Lop-nor b 230731}

$3100 \pm 110$

Shells from "yardang sediments" (erosional remains of ancient Tarim delta) at Camp H 82 E of ruined town of Lou-lan, Lop-nor. Coll. 1931 by Hörner. Comment: inner $25 \%$ was used. Diluted. $\delta \mathrm{C}^{13}=-7.6 \%$.

\section{U-285. Lop-nor a}

$$
3020 \pm 90
$$

\section{0 в.c.}

Shell layer surrounding the part used for U-286. Comment: layer corresponds to $45 \%$ of the shells. $30 \%$ was removed by washing. $\delta \mathrm{C}^{13}=-7.9 \%$.

\section{U-238. Avdat I, Israel}

\section{A.D. 1890}

$60 \pm 80$

Pieces of wood from stone wall at Avdat ( $30^{\circ} 45^{\prime} \mathrm{N}$ Lat, $34^{\circ} 45^{\prime} \mathrm{E}$ Long), Israel. Wood was supposed to be either recent roots or to belong to construction of wall, which is ca. $2000 \mathrm{yr}$ old. $\delta \mathrm{C}^{13}=-11.6 \%$.

\section{Vestspitsbergen series}

\section{Spitsbergen}

Peat and shells measured as a continuation of Vestspitsbergen series (Uppsala II and III; Feyling-Hanssen and Olsson, 1959-1960) and also to date pollen-analyzed peat. All altitudes are above mean sealevel.

\section{U-206. Skansbukta 15 M h}

$3410 \pm 230$ 1460 в.c.

Humus exaracted by hot $\mathrm{NaOH}$ from peat used for sample U-185, Skansbukta $15 \mathrm{M}$ p $\left(78^{\circ} 31.5^{\prime} \mathrm{N}\right.$ Lat, $16^{\circ} 03^{\prime} \mathrm{E}$ Long $)$, Billefjorden, Spitsbergen, dated at $4800 \pm 120$ в.P. (Uppsala III). Diluted. $\delta \mathrm{C}^{13}=-25.4 \%$.

\section{U-203. Anservika 334 $b_{1}$}

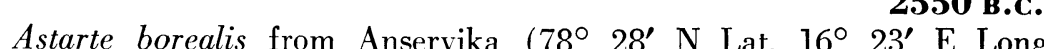

Billefjorden, Spitsbergen, $9.7 \mathrm{~m}$ alt (Feyling-Hanssen and Jørstad, 1950, 
and Feyling-Hanssen, 1955, p. 58-65). Coll. 1950 and subm. by Rolf FeylingHanssen, Paleontologisk Mus., Oslo, Norway. Comment: inner 53\% was used. $\delta \mathrm{C}^{13}=+0.1 \%$.

\section{U-204. Anservika 334 a $_{1}$}

$4160 \pm 170$

2210 в.C.

Shell layer surrounding the part used for U-203. Comment: layer corresponds to $16 \%$ of the shells; $31 \%$ was removed by washing. Diluted. $\delta \mathrm{C}^{13}$ assumed $0 \%$.

\section{U-279. Anservika 334 $c_{2}$}

Astarte borealis from Anservika ( $78^{\circ} 28^{\prime} \mathrm{N}$ Lat, $16^{\circ} 23^{\prime} \mathrm{E}$ Long), Billefjorden, Spitsbergen, $9.7 \mathrm{~m}$ alt (Feyling-Hanssen and Jørstad, 1950, p. 33 and Feyling-Hanssen, 1955, p. 58-65) . Coll. 1950 and subm. by R. W. FeylingHanssen. Comment: inner 25\% was used. Sample was also dated in 1961, in fractions corresponding to those of U.203 and U.204 (this date list) but the fractions gave too large a difference in age at that time, and two new samples were selected, fractionated, and dated. The age difference may indicate a strong contamination. 700 years corresponds to $10 \%$ contamination with prebomb material. $\delta \mathrm{C}^{13}=+0.9 \%$.

\section{U-278. Anservika $334 b_{2}$}

Shell layer surrounding the part used for U-279. Comment: layer corresponds to $30 \%$ of the shells. $\delta \mathrm{C}^{13}=+1.2 \%$.

\section{U-277. Anservika 334 a $_{2}$}

$5110 \pm 140$

3160 в.c.

Shell layer surrounding the part used for U-278. Comment: layer corresponds to $33 \%$ of the shells; $12 \%$ was removed by washing. $\delta \mathrm{C}^{13}=+1.9 \%$.

\section{U-424. Teltf jellbekken 357 c}

$9340 \pm 140$ 7390 в.с.

Astarte borealis, Arctica (= Cyprina) islandica, Saxicava arctica, Macoma calcarea, Littorina littorea from $\mathrm{S}$ of Teltfjellbekken $\left(78^{\circ} 38^{\prime} \mathrm{N}\right.$ Lat, $16^{\circ}$ 44' E Long), Brucebyen, Billefjorden, Spitsbergen, $23.0 \mathrm{~m}$ alt. Locality described by Feyling-Hanssen (1955, p. 82-86). Coll. 1950 and subm. by R. W. Feyling-Hanssen. Comment: inner $31 \%$ was used. $\delta \mathrm{C}^{13}=+2.0 \%$.

\section{U-423. Teltf jellbekken 357 b}

$9490 \pm 270$

7540 в.C.

Shell layer surrounding the part used for U-424. Comment: layer corresponds to $15 \%$ of the shells. Diluted. $\delta \mathrm{C}^{13}$ assumed $+2.0 \%$.

\section{U-422. Teltf jellbekken 357 a \\ $9140 \pm 190$ \\ 7190 в.с.}

Shell layer surrounding the part used for U-423. Comment: layer corresponds to $18 \%$ of the shells. $36 \%$ was removed by washing. $\delta \mathrm{C}^{13}=+2.3 \%$.

\section{U-261. Hornsund 1}

\section{A.D. 560}

Brown basal peat in bog, surface alt $12 \mathrm{~m}, 55$ to $60 \mathrm{~cm}$ depth, among moraine boulders, Hornsund ( $77^{\circ} 00^{\prime} \mathrm{N}$ Lat, $15^{\circ} 28^{\prime} \mathrm{E}$ Long), Spitsbergen. Bog is described by Środon (1960) and the dates are discussed by Blake, 
Środoń, and Olsson (in preparation). Coll. 1957 by A. Środoń, Inst. Botaniki, Polska Akad. Nauk, Kraków; subm. by Weston Blake Jr., Geol. Survey of Canada, Ottawa 4, Ontario. Comment: another sample from nearly the same depth in the same bog gave two different ages, both younger, when fractionated (U-202, U-275, this date list). $\delta \mathrm{C}^{13}=-23.8 \%$.

\section{U-262. Hornsund 2, p}

$620 \pm 80$

A.D. 1330

Light-brown peat from same bog as U-261, 54 to $55 \mathrm{~cm}$ depth, Hornsund. Coll. 1957 by A. Środoń; subm. by W. Blake Jr. Comment: humus fraction (U-275, this date list) was dated at $260 \pm 110$ B.P. $\delta \mathrm{C}^{13}=-24.9 \%$.

\section{U-275. Hornsund 2, h}

$260 \pm 110$

A.D. 1690

Humus extracted from the peat used for sample U-262, Hornsund. Diluted. $\delta \mathrm{C}^{13}=-27.4 \%$.

\section{U-210. Russekeila I, 55, p}

$4780 \pm 120$

Peat from same peat bog as U-212, Russekeila $\left(78^{\circ} 05^{\prime} \mathrm{N}\right.$ Lat, $13^{\circ} 47^{\prime} \mathrm{E}$ Long), Isfjord, Spitsbergen, $9.5 \mathrm{~m}$ above high tide level on a raised beach sloping from 12.5 to $7.5 \mathrm{~m}$ alt, $55 \mathrm{~cm}$ below surface, showing no frost cracks. Bog is pollen-analyzed by E. Norling. Coll. 1960 and subm. by E. Norling, Kvartärgeologiska Inst., Uppsala Univ., Uppsala. $\delta \mathrm{C}^{13}=-28.3 \%$.

\section{U-211. Russekeila I, 55, h}

$5480 \pm 130$

3530 в.c.

Humus extracted from the peat used for U-210, Russekeila, Isfjord, Spitsbergen. $\delta \mathrm{C}^{13}=-26.0 \%$.

\section{U-212. Russekeila II, 55, p}

$$
\begin{array}{r}
1090 \\
\text { A.D. } 860
\end{array}
$$

Amblystegium peat from ca. $15 \mathrm{~cm}$ depth in same peat bog as U-210, Russekeila. Coll. 1960 and subm. by E. Norling. $\delta \mathrm{C}^{13}=-29.6 \%$.

\section{U-205. Talavera $\mathrm{O}_{4} \mathrm{~h}$}

$3030 \pm 290$

1080 в.c.

Humus extracted with hot $\mathrm{NaOH}$ from the peat used for sample. U-186, Talavera $\mathrm{O}_{4} \mathrm{p}\left(78^{\circ} 15^{\prime} \mathrm{N}\right.$ Lat, $20^{\circ} 50^{\prime} \mathrm{E}$ Long $)$, Barentsöya, Spitsbergen, dated at $6000 \pm 400$ B.P. (Uppsala III). Diluted. $\delta \mathrm{C}^{13}=-22.0 \%$.

\section{Nordaustlandet series}

Shells, peat, and humus collected to confirm previously obtained results on land uplift (e.g. Olsson and Blake, 1961-1962), to get a measure of accumulation rate of sediments, and to date pollen-analyzed peat.

\section{U-227. Trippvatnet $\mathbf{H} / \mathbf{I}$}

$4880 \pm 120$

\section{B.C.}

Limnic peat and algal mud from 59 to $68 \mathrm{~cm}$ above bottom of pollenanalyzed sediment core, Trippvatnet $\left(80^{\circ} 01^{\prime} \mathrm{N}\right.$ Lat, $18^{\circ} 47^{\prime} \mathrm{E}$ Long $)$, Nordaustlandet, Spitsbergen, $5.2 \mathrm{~m}$ alt. Below sediment core was clay with pieces of schist. Described by Häggblom (1963). Coll. 1958 and subm. by Anders Häggblom, Geog. Inst., Stockholms Univ., Stockholm, Sweden. Comment: a sample from the same sediment and corresponding level was dated at 
$5290 \pm 400$, U-93, corrected to oxalic acid (published as $5160 \pm 400$, Uppsala II). Diluted. $\delta \mathrm{C}^{13}=-26.3 \%$.

\section{U-228. Krystallvatnet $\mathrm{H} / \mathbf{2 8 - 5 8}$}

$4940 \pm 100$ 2990 в.C.

Limnic peat (Fontinalis type) from 98.5 to $104.5 \mathrm{~cm}$ above bottom of pollen-analyzed sediment core with total length of $130 \mathrm{~cm}$, Krystallvatnet $\left(79^{\circ}\right.$ $58^{\prime} \mathrm{N}$ Lat, $18^{\circ} 40^{\prime} \mathrm{E}$ Long), Nordaustlandet, Spitsbergen, $62 \mathrm{~m}$ alt. Below bottom of core was firm clay. Described by Häggblom (1963). Coll. 1958 and subm. by A. Häggblom. Comment: a sample from same sediment, but coll. 10 $\mathrm{cm}$ above bottom of core, was dated at $10,030 \pm 550, \mathrm{U}-92$, corrected to oxalic acid (published as $9900 \pm 550$, Uppsala II). $\delta \mathrm{C}^{13}=-27.3 \%$.

\section{U-263. Lady Franklinf jorden 48}

$$
\begin{aligned}
& 13,470 \begin{array}{r}
+530 \\
\mathbf{- 5 0 0}
\end{array} \\
& 11,520 \text { в.с. }
\end{aligned}
$$

Shells and calcareous algae (Lithothamnion, Balanus, and probably Hiatella and $M y a)$ from 2 collecting points in till at Lady Franklinfjorden $\left(80^{\circ}\right.$ $12^{\prime} \mathrm{N}$ Lat, $18^{\circ} 42^{\prime} \mathrm{E}$ Long), Nordaustlandet, Spitsbergen, 1.5 to $2 \mathrm{~m}$ alt. Shells are part of matrix of till, and thus give a limiting date for the time of glacier advance. Beach gravel overlies the till, and in one place peat dated at $3960 \pm$ 100 B.P., U-276, occurs between the till and the beach gravel. Coll. 1958 by R. Bergström and W. Blake, Jr., and subm. by W. Blake, Jr. Pollen-analyzed by E. Norling (in preparation). Comment: only ca. $8 \mathrm{~g}$ was subm., too little to allow thorough pretreatment, and condition of shells was very poor, so result should be regarded as minimum age. Outer $22 \%$ was removed by washing. Diluted. $\delta \mathrm{C}^{13}=-2.6 \%$.

\section{U-276. Lady Franklinf jorden 49}

$3960 \pm 100$ 2010 в.c.

Plant remains mixed with till (?) or mud above main till at Lady Franklinfjorden $\left(80^{\circ} 12^{\prime} \mathrm{N}\right.$ Lat, $18^{\circ} 42^{\prime}$ E Long), Nordaustlandet, Spitsbergen, $2 \mathrm{~m}$ alt. Shells in underlying till dated at >13,000 B.P., U-263. Coll. 1958 and subm. by W. Blake, Jr. $\delta \mathrm{C}^{13}=-23.1 \%$.

General Comments: the results obtained from Spitsbergen confirm previous results in showing that land uplift for the last $8000 \mathrm{yr}$ has been very slow.

As shown earlier, great care must be taken in pretreatment of samples. It is not sufficient to wash shells so that e.g. 10 to $20 \%$ of the shells are removed; samples must be carefully selected from bulk material and treated individually.

Large age discrepancies between peat and humus fractions of sediments in frozen ground (Olson and Broecker, 1958) have also been observed in 4 samples presented here. The reasons are still obscure, but one may be that cryoturbation causes vertical movement of soil and stones. Water-borne humus may be carried to various depths in such an environment. Wind-borne material may also easily contaminate the samples.

\section{Åland series}

\section{E. Aland}

Gyttja from Åland, Finland, pollen-analyzed to date immigration of spruce (Picea) and cultivation of rye (Secale) on the main island. Coll., subm., 
and pollen-analyzed by Magnus Fries, Växtbiologiska Inst., Uppsala Univ., Uppsala, Sweden.

\section{U-231. Söderängsmossen 175 to 180}

$$
\begin{array}{r}
1740 \\
\text { A.D. } 210
\end{array}
$$

Gyttja from the bog Söderängsmossen $\left(60^{\circ} 18^{\prime} \mathrm{N}\right.$ Lat, $20^{\circ} 7^{\prime} \mathrm{E}$ Long $)$, Saltvik parish, Åland, Finland. Sample from the marked increase of Picea, at beginning of Pollen Zone IX (Jessen), 175 to $180 \mathrm{~cm}$ below the reference level. Coll. 1961. $\delta \mathrm{C}^{13}=-26.0 \%$.

\section{U-232. Söderängsmossen 172.5 to 175 and} 180 to 182.5

$$
\begin{aligned}
& 2050 \pm 120 \\
& 100 \text { B.C. }
\end{aligned}
$$

Gyttja above and below sample U-231, from 172.5 to $175 \mathrm{~cm}$ and 180 to $182.5 \mathrm{~cm}$ level, measured to check the unexpectedly low date of $\mathrm{U} \cdot 231 . \delta \mathrm{C}^{13}=$ $-34.5 \%$.

\section{U-233. Dalkarbyträsk 575 to 580}

Gyttja from Dalkarbyträsk $\left(60^{\circ} 09^{\prime} \mathrm{N}\right.$ Lat, $19^{\circ} 57^{\prime} \mathrm{E}$ Long), Jomala parish, Ảland, Finland. Sample from the marked increase of Picea, at beginning of Pollen Zone IX (Jessen), 575 to $580 \mathrm{~cm}$ below (frozen) lake surface. Coll. 1962. $\delta \mathrm{C}^{13}=-28.2 \%$.

\section{U-234. Dalkarbyträsk 540 to 546}

$1610 \pm 90$

Gyttja from Dalkarbyträsk $\left(60^{\circ} 09^{\prime} \mathrm{N}\right.$ Lat, $19^{\circ} 57^{\prime}$ E Long), Jomala parish, Åland, Finland. Sample from a level indicating beginning of cultivation of rye, Pollen Zone IX (Jessen), 540 to $546 \mathrm{~cm}$ below (frozen) lake surface. Coll. 1962. $\delta \mathrm{C}^{13}=-29.1 \%$.

\section{U-236. Dalkarbyträsk 500 to 506}

$1540 \pm 100$

Gyttja from Dalkarbyträsk $\left(60^{\circ} 09^{\prime} \mathrm{N}\right.$ Lat, $19^{\circ} 57^{\prime}$ E Long $)$, Jomala parish, Åland, Finland, from a level indicating a possible decrease of cultivation of rye, Pollen Zone IX (Jessen), 500 to $506 \mathrm{~cm}$ below (frozen) lake surface. Coll. 1962. $\delta \mathrm{C}^{13}=-28.7 \%$

\section{U-235. Kvarnboträsk 174 to 180}

$$
2080 \pm 90
$$

Gyttia from Kvarnboträk $\left(60^{\circ} 17^{\prime} \mathrm{N}\right.$ parish, Aland, Finland, from the (600 $17^{\circ}$ N Lat, $20^{\circ} 04^{\prime} \mathrm{E}$ Long), Saltvik arked increase of Picea, at beginning of Pollen Zone IX (Jessen), 174 to $180 \mathrm{~cm}$ below sediment surface. Coll. 1962. $\delta \mathrm{C}^{13}=-30.7 \%$.

\section{F. Sweden}

\section{U-445. Submarine peat, Laholm bay}

$10,060 \pm 140$

Dark brown submarine peat, well humified and containing macrofossils of Betula, Equisetum, Phragmites and Carex, from bay outside Laholm $\left(56^{\circ}\right.$ $31^{\prime} \mathrm{N}$ Lat, $12^{\circ} 48^{\prime} \mathrm{E}$ Long), Halland, Sweden; water depth ca. $16 \mathrm{~m}$. Pollen analysis (Magnus Fries) implies that peat is derived from a fen and belongs to Pollen Zone IV (Jessen). Peat appeared to be in situ when dredged, with no overlying sediment; judging from its altitude, locality should have been above 
sealevel at time of date. Recent molluscs were removed before dating. Described by Wærn (1964). Coll. 1963 on the Sunbeam expedition by Mats Wærn and subm. by Mtgnus Fries, both Växtbiologiska Inst., Uppsala Univ., Uppsala, Sweden. $\delta \mathrm{C}^{13}=-28.0 \%$.

U-428. Levide

$9830 \pm 140$

7880 в.с.

Wood from trunk of Pinus silvestris from Hallbåter, Levide $\left(57^{\circ} 16^{\prime} \mathrm{N}\right.$ Lat, $18^{\circ} 15^{\prime} \mathrm{E}$ Long), Gotland, Sweden, ca. $1500 \mathrm{~m} \mathrm{~S}$ of Ancylus ridge below layer of sand and gravel about $1.9 \mathrm{~m}$ deep. Forest was destroyed by a transgression of the Baltic. Coll. 1961 and subm. by Bengt Pettersson, Växtbiologiska Inst., Uppsala Univ., Uppsala, Sweden. $\delta \mathrm{C}^{13}=-25.1 \%$.

U-429. Bunn, Bunge

$2940 \pm 90$

990 в.C.

Charcoal of Pinus silvestris from Bunn, Bunge $\left(57^{\circ} 52^{\prime} \mathrm{N}\right.$ Lat, $19^{\circ} \mathrm{E}$ Long), Gotland, Sweden, found with potsherds and mixed with sand. Supposedly from a dwelling-place buried by sand, ca. 2 m thick. Coll. 1957 and subm. by B. Pettersson. $\delta \mathrm{C}^{13}=-24.2 \%$.

\section{U-427. Nyköping boat}

$1095 \pm 80$

Pine wood, part of boat, in excavation for basement of Nyköping Town Hall (58 $45^{\prime} \mathrm{N}$ Lat, $17^{\circ} 1^{\prime}$ E Long), Södermanland, Sweden. Boat imbedded in Phragmites peat member of lake deposit, pollen-dated as lower Zone IX, underlain by mud and Baltic sediments. Diatom analysis by Maj-Britt Florin, pollen analysis by Thorolf Candolin; described by Florin and Olsson (1964). Coll. 1959 and subm. by Sten Florin, Kvartärgeologiska Inst., Uppsala Univ., Uppsala, Sweden. $\delta \mathrm{C}^{13}=-25.7 \%$.

\section{Land Uplift series, Eastern Central Sweden}

Sediments from eastern Central Sweden, coll. from ancient lakes developed by isolation from the sea, to determine time and rate of land uplift in this part of Sweden. Described by Maj-Britt Florin (1944) and Sten Florin (1944, 1947, and 1948).

\section{U-218. Grässjön II}

$8320 \pm 140$

Clay-gyttja from the lake Grässjön $\left(59^{\circ} 10^{\prime} \mathrm{N}\right.$ Lat, $14^{\circ} 31^{\prime} \mathrm{E}$ Long$)$, Nysund parish, Närke, Sweden; drainage threshold at $121.1 \mathrm{~m}$ alt. Sediment from level 200 to $207 \mathrm{~cm}$ below surface. Diatom and pollen analysis performed by Maj-Britt Florin (1944) and subsequent analysis performed by G. PiehlLinnman and T. Candolin. Analyses imply that this sediment was deposited shortly after lake had been isolated from sea in early time of Zone IV (Jessen) before increase of Corylus. Coll. 1959 and subm. by Sten Florin. Diluted. $\delta \mathrm{C}^{13}=-19.2 \%$.

\section{U-269. Grässjön I}

$8770 \pm 190$ $\mathbf{5 8 2 0}$ в.с.

Gyttja from the lake Grässjön $\left(59^{\circ} 10^{\prime} \mathrm{N}\right.$ Lat, $14^{\circ} 31^{\prime} \mathrm{E}$ Long $)$, Nysund parish, Närke, Sweden, drainage threshold at $121.1 \mathrm{~m}$ alt, from level 190 to $198 \mathrm{~cm}$ below surface and taken above sample U-218. Diatom and pollen 
analysis performed by Maj-Britt Florin and others (see U-218). Coll. 1959 and subm. by Sten Florin. Comment: this sample more organogenic than sample U-218. Diluted. $\delta \mathrm{C}^{13}=-24.4 \%$.

\section{Late Pleistocene vegetational series, Eastern Central Sweden}

Sediments from ancient lakes in W Kolmården, E Central Sweden, described by M.-B. Florin (1944) and S. Florin (1944, 1947, and 1948). Coll. by M.-B. and S. Florin; subm. by M.-B. Florin. Diatom and pollen analyses by M.-B. Florin.

\section{U-217. Långa Getsjön III}

$9140 \pm 260$

Detrital gyttja with fine sand from 415 to $419 \mathrm{~cm}$ below surface, Långa Getsjön (58 $42^{\prime}$ N Lat, $16^{\circ} 16^{\prime} \mathrm{E}$ Long), alt $120 \mathrm{~m}$ (MSL). Coll. 1962. Pollen analysis implies Pre-Boreal time, Pollen Zone IV (Jessen). Diluted. $\delta \mathrm{C}^{13}=$ $-31.7 \%$.

\section{U-426. Långa Getsjön II}

$10,210 \pm 140$

8260 в.c.

Clay-gyttja from 440 to $445 \mathrm{~cm}$ below surface, Långa Getsjön $\left(58^{\circ} 42^{\prime} \mathrm{N}\right.$ Lat, 16 $16^{\prime}$ E Long). Coll. 1963. Pollen analysis implies Pollen Zone IV (Jessen). Sedimented in fresh water according to diatom analysis. $\delta \mathrm{C}^{13}=$ $-21.8 \%$.

\section{U-425. Långa Getsjön I}

$$
\begin{aligned}
& 19,700 \begin{array}{r}
+1100 \\
\mathbf{9 0 0 0}
\end{array} \\
& 17,750 \text { в.с. }
\end{aligned}
$$

Clay with one sandy layer from 455 to $465 \mathrm{~cm}$ below surface, Långa Getsjön (58 42' N Lat, 16 ${ }^{\circ}$ 16’ E Long). Coll. 1963. Pollen analysis implies late Pollen Zone III or early Pre-Boreal Pollen Zone IV (Jessen). Sedimented in fresh water according to diatom analysis. Comment: this sample and varved glacial clay samples from Lugnvik (U-213, U-214, and U-260, this date list), show that too high ages may be obtained if the clay contains allochtonous material. Diluted. $\delta \mathrm{C}^{13}=-26.6 \%$.

\section{U-420. Stuggölen I}

$9930 \pm 140$

7980 в.с.

Clay and clay-gyttja from 430 to $435 \mathrm{~cm}$ below surface, Stuggölen $\left(58^{\circ}\right.$ $42.5^{\prime} \mathrm{N}$ Lat, $16^{\circ} 22^{\prime} \mathrm{E}$ Long), alt $95 \mathrm{~m}$. Coll. 1963. According to pollen analysis sample is correlated with Pollen Zone IV (Jessen), and diatoms show influence of the Yoldia Sea. $\delta \mathrm{C}^{13}=-17.5 \%$.

\section{U-421. Stuggölen II}

$9300 \pm 130$

7350 в.с.

Detrital gyttja from 425 to $430 \mathrm{~cm}$ below surface, Stuggölen ( $58^{\circ} 42.5^{\prime} \mathrm{N}$ Lat, $16^{\circ} 22^{\prime}$ E Long), immediately overlying U-420. According to pollen and diatom analysis sample is correlated with Pollen Zone IV (Jessen) and sedimentation occurred in fresh water. $\delta \mathrm{C}^{13}=-17.9 \%$.

\section{U-219. Dragby sedge bog 16}

Sedge dy and gyttja from Dragby $\left(59^{\circ} 59^{\prime} \mathrm{N}\right.$ Lat, $17^{\circ} 35^{\prime} \mathrm{E}$ Long), 
Skuttunge parish, Uppland, Sweden. Bog is in a kettle, drainage level at 28.5 $\mathrm{m}$ alt. Sample from upper part of Pollen Zone VIII near boundary of Pollen Zone IX (Jessen), below the increase of Picea. Pollen analysis by T. Candolin. Sample near isolation contact according to diatom analysis by M.-B. Florin. Described by M.-B. and S. Florin (1960) and S. Florin (1963). Samples of archaeologic interest from Dragby are given in Uppsala II and III, Stockholm $\mathrm{IV}$ and V, and this paper. Coll. 1962 and subm. by S. Florin. $\delta \mathrm{C}^{13}=-25.0 \%$.

\section{Varved glacial clay series, Lugnvik}

Organic material deposited in glacial varves +29 to +82 , Borell-Offerberg's (1955) time-scale, at Lugnvik ( $62^{\circ} 55^{\prime} \mathrm{N}$ Lat, $17^{\circ} 55^{\prime} \mathrm{E}$ Long). Concentration of organic material was almost as high as $1 \%$. Although organic material could be expected to be mainly allochtonous and thus probably old, pollen analysis (Hörnsten) proved that part of it is contemporaneous with the sediment. Samples were determined partly to give information about origin of deposited material and partly to prove that selection of samples is important. Only authigenic material in sediments may be used for dating. Dates given here by the varve chronology are not exact since there is some uncertainty concerning the extrapolation to present time. Samples are described by Hörnsten and Olsson (1964). Coll. 1962 and subm. by Åke Hörnsten, Kvartärgeologiska Inst., Uppsala Univ., Uppsala. Comment: due to the low carbon content and the high ages a small contamination with modern material may change the result for U-213 and U-214 considerably so that the dates given should be regarded as lower limits. The insoluble (in hot $\mathrm{NaOH}$ ) fractions are thus supposed to be older than $30,000 \mathrm{yr}$ and $34,000 \mathrm{yr}$, respectively. A similar sample from Södermanland (U-425) has also been dated.

U-260. Lugnvik varves, +29 to +55

$\geqslant 37,000$

Varved clay dated by varved clay chronology at 6894 to $6868 \mathrm{yr}$ в.c. Clay content about $43 \%(<2 \mu) . \delta \mathrm{C}^{13}=-28.6 \%$.

$$
\begin{array}{ll}
\text { U-213. Lugnvik varves, }+56 \text { to }+82(\text { a) } & \mathbf{3 0 , 0 0 0}+\mathbf{2 5 0 0} \\
& \mathbf{2 8 , 0 0 0} \text { в.c. }
\end{array}
$$

Varved clay dated by varved clay chronology at 6867 to 6841 yr B.c. Clay content about $38 \%(<2 \mu) . \delta \mathrm{C}^{13}=-29.4 \%$.

$$
\begin{array}{ll}
\text { U-215. Lugnvik varves, }+56 \text { to }+82(\text { ah }) & 9000+1400 \\
& 7000 \text { B.c. }
\end{array}
$$

Humus extracted with hot $\mathrm{NaOH}$ from clay used for U-213. Diluted.

$$
\begin{array}{ll}
\text { U-214. Lugnvik varves, +56 to }+82(\mathbf{b}) & 34,000+2200 \\
& \begin{array}{l}
\mathbf{3 2 , 0 0 0} \text { в.C. }
\end{array}
\end{array}
$$


II. ARCHAEOLOGIC SAMPLES

\section{U-274. Takht-i-Suleiman}

A. Iran

Muck from Takht-i-Suleiman ( $36^{\circ} 37^{\prime} \mathrm{N}$ Lat, $47^{\circ} 14^{\prime}$ E Long), Azerbaidjan, Iran, found in pit with artifacts about $1500 \mathrm{yr}$ old. Coll. 1962 and subm. by Carl Nylander and Lars Gezelius, Inst. för Klassisk Fornkunskap och Antikens Historia, Uppsala Univ., Uppsala, Sweden. $\delta \mathrm{C}^{13}=-19.9 \%$.

\section{U-267. San Giovenale 62-183 b \\ $\mathbf{2 4 2 0} \pm \mathbf{8 0}$ \\ 470 в.c.}

B. Italy

Charcoal from San Giovenale $\left(42^{\circ} \mathrm{N}\right.$ Lat, $12^{\circ} \mathrm{E}$ Long $)$, province of Viterbo, Italy, found in fill with sherds dating from 600 to 300 B.c. Coll. 1962 and subm. by C. Nylander. $\delta \mathrm{C}^{13}=-22.9 \%$.

\section{U-268. San Giovenale 62-159 d \\ $2390 \pm$ B.P. \\ 440 в.c.}

Charcoal from San Giovenale ( $42^{\circ} \mathrm{N}$ Lat, $12^{\circ} \mathrm{E}$ Long), di Viterbo, Italy, found in fill with sherds dating from 600 to 300 B.C. Coll. 1962 and subm. by C. Nylander. $\delta \mathrm{C}^{13}=-24.7 \%$.

$$
\text { C. Ireland }
$$

\section{Raheennamadra series, Ireland}

Wood and charcoal from a so-called ring-fort from Raheennamadra $\left(52^{\circ}\right.$ $3^{\prime} \mathrm{N}$ Lat, $8^{\circ} 3^{\prime} \mathrm{W}$ Long) near church of Knocklong in the Golden Vale, Co. Limerick, Ireland. The late Seán Ó Riordáin suggested collaboration with Swedish archaeologists and his intention was fulfilled in 1960-61 by Michael O'Kelly of Cork and Mårten Stenberger of Uppsala. The ring-fort has total diam of $45 \mathrm{~m}$ including surrounding bank with an associated outer fosse. Diam of raised platform within the bank (the site) is $20 \mathrm{~m}$ and close to the bank at $\mathrm{SW}$ is souterrain house, $8.5 \times 2.5 \mathrm{~m}$, of 2 rooms with stone walls, $2 \mathrm{~m}$ high. In center of the site are faint traces of something believed to be a hut of wattlework. Site is described in a preliminary report by Stenberger (1962). Sample coll. 1961 and subm. by Mårten Stenberger, Inst. för Nordisk och Jämförande Fornkunskap, Uppsala Univ., Uppsala, Sweden.

\section{U-240. Raheennamadra 1 a}

$$
1280 \pm 120
$$

\section{A.d. 670}

Wood from wooden post supposed to have supported roof of souterrain house. $\delta \mathrm{C}^{13}=-28.5 \%$.

\footnotetext{
IT_A. Roheannamadra $1 \mathrm{~h}$
}

$1430 \pm 130$ 
U-243. Raheennamadra 2 b

Same piece of wood as U-242 but new pretreatment and combustion. $\delta \mathrm{C}^{13}=-24.9 \%$.

\section{U-244. Raheennamadra 3 a}

$$
1330 \pm 110
$$

A.D. 620

Charcoal frem $\log$ on hearth built of clay outside and above top of $\mathrm{E}$ gable-wall of souterrain. $\delta \mathrm{C}^{13}=-23.6 \%$.

\section{U-245. Raheennamadra 3 b}

$$
1300 \pm 120
$$

Same charcoal sample as U-244 but new pretreatment and combustion. $\delta \mathrm{C}^{13}=-24.6 \%$.

\section{U-246. Raheennamadra 4 a}

$1200 \pm 110$

Charcoal from hearth in $\mathrm{E}$ end of souterrain. $\delta \mathrm{C}^{13}=-24.0 \%$.

\section{U-247. Raheennamadra 4 b}

Same charcoal sample as U-246 but new pretreatment and combustion. $\delta \mathrm{C}^{13}=-26.7 \%$.

\section{U-248. Raheennamadra 5}

$1840 \pm 110$ A.D. 110

Charcoal from a dark layer, assumed to be a hearth, in a trial trench within what was supposed to be a hut, $114 \mathrm{~cm}$ below arbitrary datum. $\delta \mathrm{C}^{13}=$ $-26.7 \%$.

\section{Dragby series}

$$
\text { D. Sweden }
$$

Resin and charcoal from Dragby ( $59^{\circ} 59^{\prime} \mathrm{N}$ Lat, $17^{\circ} 35^{\prime} \mathrm{E}$ Long), Skuttunge parish, Uppland, Sweden. Results of the excavations and geological investigations are given by Stenberger $(1960,1961)$, M.-B. and S. Florin (1960), Olsson (1960), Gräslund (1961), Jaanusson and Silvén (1962), Rydh (1962), Damell and Sjögren (1962), Florin (1963), and Gejvall (1963). Coll. by students and subm. by M. Stenberger. Other samples have been dated previously (Uppsala II and III; Stockholm IV and V).

\section{U-201. Dragby 335 B}

$2070 \pm 100$

Resin from Grave 335 B. Coll. 1960. $\delta \mathrm{C}^{13}=-29.1 \%$.

U-403. Dragby 325

110 в.C. $-26.5 \%$.

Resin from Grave 325, attributed to Early Iron Age. Coll. 1963. $\delta \mathrm{C}^{13}=$

\section{U-400. Dragby $359 \mathrm{~V}$}

$2340 \pm 170$

390 в.c.

Charcoal from Grave $359 \mathrm{~V}$, attributed to Early Iron Age. Comment: diluted. $\delta \mathrm{C}^{13}=-29.4 \%$. 


\section{U-404. Dragby UO X, G3}

$$
2830 \pm 80
$$

Charcoal from Pit No. 3 above layer of brittle burnt stones, 10 to $15 \mathrm{~cm}$ thick, on bottom of pit, one of several pits near Grave field, probably used for cooking. Sampled level consists of black clayey soil and black soil with gravel, both containing charcoal. Coll. 1963 by Per Kåks. $\delta C^{13}=-23.0 \%$.

\section{CROSS-CHECK SAMPLES}

\section{U-239. Lago di Nemi}

$$
\begin{gathered}
2120 \pm 80 \\
170 \text { B.C. }
\end{gathered}
$$

Wood from Roman ships at Lake Nemi $\left(41^{\circ} 43^{\prime} \mathrm{N}\right.$ Lat, $01^{\circ} 34^{\prime} \mathrm{E}$ Long), Italy. Ships are attributed to Emperor Caligula (A.D. 37 to 41). Subm. by C. Cortesi and F. Bella, $\mathrm{C}^{14}$ Laboratory, Ist. di Geochim. dell Università Roma, Italy. Comment: for this determination the same gas was used as for U-68 (Uppsala I), published as $1980 \pm 70$ and $\delta \mathrm{C}^{13}=+0.1 \%$. These data, when recalculated to oxalic acid and PDB standards, give 2100 B.P. and $-24.1 \%$, i.e. are indistinguishable from measurements made after 5 years' storage. For reference to other determinations see U-68 (Uppsala I, p. 100). $\delta \mathrm{C}^{13}=$ $-23.1 \%$.

Date lists:

\section{REFERENCES}

$\begin{array}{ll}\text { Arizona III } & \text { Damon and Long, 1962 } \\ \text { Stockholm IV } & \text { Engstrand and Östlund, 1962 } \\ \text { Stockholm V } & \text { Östlund and Engstrand, 1963 } \\ \text { Uppsala I } & \text { Olsson, 1959 } \\ \text { Uppsala II } & \text { Olsson, 1960 } \\ \text { Uppsala III } & \text { Olsson and others, 1961 } \\ \text { USGS II } & \text { Rubin and Suess, 1955 }\end{array}$

Borell, R., and Offerberg, J., 1955, Geokronologiska undersökningar inom Indalsälvens dalgång mellan Bergeforsen och Ragunda: Sveriges Geol. Undersökning, Ser. Ca, v. 31.

Craig, Harmon, 1961, Mass-spectrometer analyses of radiocarbon standards: Radiocarbon, v. 3 , p. $1-3$.

Damell, David, and Sjögren, Ingvar, 1962, Hjulkorsgravar på Dragbyfältet: Tor, v. 8, p. 95-104.

Damon, P. E., and Long, A., 1962, Arizona radiocarbon dates III: Radiocarbon, v. 4, p. $239-249$.

Engstrand, Lars G., and Östlund, H. Göte, 1962, Stockholm natural radiocarbon measurements IV: Radiocarbon, v. 4, p. 115-136.

Ericson, D. B., Broecker, W. S., Kulp, J. L., and Wollin, Goesta, 1956, Late Pleistocene climates and deep-sea sediments: Science, v. 124, p. 385-389.

Eriksson, K. Gösta, and Olsson, Ingrid U., 1963, Some problems in connection with $\mathrm{C}^{14}$ dating of tests of Foraminifera: Bull. Geol. Inst. Uppsala, v. 42, p. 1-13.

Eriksson, K. Gösta, 1964, A Late-Pleistocene sediment sequence in the Western Mediterranean Sea. Studies of sediment core no. 210: Rept. Swedish Deep-Sea Exped., VIII, no. 7.

Feyling-Hanssen, Rolf W., 1955, Stratigraphy of the marine Late-Pleistocene of Billefjorden, Vestspitsbergen: Norsk Polarinst., skr., no. 107, 186 p.

Feyling-Hanssen, Rolf W., and Jørstad, F. A., 1950, Quaternary fossils from the Sassenarea in Isfjorden, West-Spitsbergen: Norsk polarinst. skr., no. 94, 85 p.

Feyling-Hanssen, Rolf W., and Olsson, Ingrid, 1959-1960, Five radiocarbon datings of Post Glacial shorelines in Central Spitsbergen: Norsk Geog. Tidsskr., v. 17, p. 122-131.

Florin, Maj-Britt, 1944, En sensubarktisk transgression i trakten av södra Kilsbergen enligt diatomacésuccesionen i områdets högre belägna fornsjölagerföljder: Geol. fören. Stockholm förh., v. 66, p. 417-448.

Florin, Maj-Britt, and Florin, Sten, 1960, Naturhistorisk utveckling vid Dragby under bronsåldern. Från en påbärjad undersökning över områdets kvartärgeologi: Tor, v. 6, p. 87-121. 
Florin, Sten A., 1944, Havsstrandens förskjutningar och bebyggelseutvecklingen i östra Mellansverige under senkvartär tid. I. Allmän översikt: Geol. fören. Stockholm förh., v. 66, p. $551-634$.

1947, Diskussion om senglacialens nivåförändringar och klimatutveckling: Geol. fören. Stockholm förh., v. 69, p. 221-232.

1948, Havsstrandens förskjutningar och bebyggelseutvecklingen i östra Mellansverige under senkvartär tid. II. De baltiska strandbildningarna och stenåldersboplatsen vid Dammstügan nära Katrineholm: Geol. fören. Stockholm förh., v. 70, p. $17-202$.

Florin, Sten, and Olsson, Ingrid U., 1964, Ett båtfynd från vikingatiden i torvmark under Rådhuset i Nyköping: Geol. fören. Stockholm förh., v. 86, in press.

Fries, Magnus, 1964, Kvartärbotanisk undersökning av submarine tory från Laholmsbukten. (Summary, A botanical investigation of the late Quaternary submarine peat from Laholm Bay, West Coast of Sweden ) : Svensk botan. tidskr., v. 58, p. 315-319.

Gejvall, Nils-Gustav, 1963, Skelettmaterialet i Dragby hällkista: Tor, v. 9, p. 85-122.

Gräslund, Bo, 1961, Den "södra gravslätten" i Dragby. Några gravtyper: Tor, v. 7, p. 205219.

Häggblom, Anders, 1963, Sjöar på Spetsbergens Nordostland: Ymer, p. 76-105.

Hörner, Nils G., and Chen, Parker C., 1935, Alternating lakes: Geog. Ann. Stockholm, v. 17 , p. 145-166.

Hörnsten, Äke and Olsson, Ingrid U., 1964, En C $\mathrm{C}^{14}$-datering av glaciallera från Lugnvik, Ängermanland: Geol. fören. Stockholm förh., v. 86, in press.

Jaanusson, Hille, and Silvén, Ulla, 1962, Undersökningen av Dragbyröset 88: Tor, v. 8, p. 5-44.

Norin, Erik, in preparation, Description to Sheet NK-46, HAMI. Sven Hedin Central Asia Atlas 1:1,000,000.-Sino-Swed. Exped., Pub. no. 47. in Sven Hedin Central Asia Atlas 1:1,000,000.-Sino-Swed. Exped., Pub. no. 47.

Olson, E. A., and Broecker, W. S., 1958, Sample contamination and reliability of radiocarbon dates, New York Acad. Sci. Trans., ser. II, v. 20, no. 7, p. 593-604.

Olsson, Ingrid, 1958, A $\mathrm{C}^{14}$ dating station using the $\mathrm{CO}_{2}$ proportional counting method: Arkiv Fysik, v. 13, p. 37-60.

1959, Uppsala natural radiocarbon measurements I: Am. Jour. Sci. Radioc. Supp., v. 1, p. 112-128. 1960a, Uppsala natural radiocarbon measurements II: Am. Jour. Sci. Radioc. Supp., v. 2, p. 112-128. 122.124

Olsson, Ingrid U., and Blake, Weston, Jr., 1961-1962, Problems of radiocarbon dating of raised beaches, based on experience in Spitsbergen: Norsk Geog. Tidsskr., v. 18, p. $47-64$.

Olsson, Ingrid, Cazeneuve, Horacio, Gustavsson, John, and Karlén, Ingvar, 1961, Uppsala natural radiocarbon measurements III: Radiocarbon, v. 3, p. 81-85.

Olsson, Ingrid U., and Eriksson, K. Gösta, 1964, Remarks on $\mathrm{C}^{14}$ dating of shell material in sea sediment: Deep-Sea Research, in press.

Östlund, H. Göte, and Engstrand, Lars G., 1963, Stockholm natural radiocarbon measurements V: Radiocarbon, v. 5, p. 203-277.

Rubin, Meyer, and Suess, Hans E., 1955, U. S. Geological Survey radiocarbon dates II: Science, v. 121 , p. $481-488$

Räydh, Stig, 1962, Dragbfältet kring röse 88: Tor, v. 8, p. 45-94.

Srodoń, A., 1960, Pollenspectra from Spitsbergen: Folia Quaternaria, v. 3, p. 1-17.

Stenberger, Mårten, 1960, Gravfältet vid sockenmötet. Dragby i Skuttunge, orientering och problem: Tor, v. 6 , p. 63-86.

1961, Dragbyröset 88: Tor, v. 7, p. 184-190.

1962, Raheennamadra-"den lilla hundens gård": Tor, v. 8, p. 252-259.

Todd, Ruth, 1958, Foraminifera from Western Mediterranean deep-sea cores: Rept. Swedish Deep-Sea Exped., v. 8a, no. 3, p. 167-217.

Wiern, Mats, 1964, En algbevuxen torvbotten i Laholmsbukten. (Summary: A peat bottom with algal growth in Laholm Bay, West coast of Sweden) : Svensk botan. tidskr., v. 58 , p. 309-314. 